\title{
Adverse Event Relationship to Non Study Treatment
}

National Cancer Institute

\section{Source}

National Cancer Institute. Adverse Event Relationship to Non Study Treatment. NCI

Thesaurus. Code C83210.

An indication or description of the relationship of an adverse event to a non-study treatment. 